\begin{tabular}{ll} 
植 田 伸 夫 & スフィソゴンン塩基のガスクロマトグラフィー \\
Nobuo UETA & グリセリドのガスクロドラフィー \\
東京大学医学部生化学教室 & リソ脂質のガスクロマトグラフィー \\
\hline
\end{tabular}

(I) はじめに

脂質領域でのガスクロマトグラフィー 脂肪酸のガスクロマトグラフィー

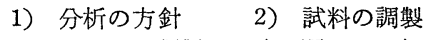

3） カラムの調製 4) 運 転

5) 結果の検討

（II）グリセロールおよび長鎖アルコールのガスクロ マトグラフィー

スフィンゴシン塩基のガスクロマトグラフィー グリセリドのガスクロマトグラフィー

糖脂質のガスクロマトグラフィー

前回は，脂質の構成分のうち，脂肪酸とそれと同じ立 場にある脂肪族アルデヒドのガスクロマトグラフ法を, 未経験の方を念頭に打いて述べました.

今回は, ひきつづき脂肪酸に相対するグリセロール, あるいは長鎖塩基などのガスクロマトグラフィーと, グ リセリド，リン脂質などをそのままで分析することを試 みている現在の進歩について触れたいと思います.

\section{グリセロールおよび長鎖アルコールのガスクロ マトグラフィー}

グリセロールはグリセロ脂質一般に含まれ, その構造 は明膫ですが, 脂質分析上, リンや脂肪酸とのモル比を 決定する必要のある場合がしばしばあります．また，高

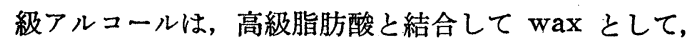
植物, 魚類, 昆虫など, かなり広範に分布しています. その種類は脂肪酸と同程度にあると考えてよいでしょう。

また, diol lipid*といわれる一群は, 自然界の分布は上記のものよりはるかに 少ないのですが, ブタン-1,3-ジオール やへキサン-1,6-ジオールなど, いろい

* L. D. Bergelson : "Progress in the Chemistry of Fats and Other Lipids", Vol. X, 241 (1969).

** A. Rajiah, M. R. Subbaram and K. T. Achaya : J. Chromatog., 38 , 35 (1968).

*** F. M. Archibald and V. P. Skipski : J. Lipid Res., 5, 314 (1966).

**** M. E. Mason, M. E. Eager and G. R. Walker : Anal. Chem., 36, 587 (1964).

***** G. A. R. Decroix, J. G. Gobert and R.De Deurwaerder: Anal. Biochem., 25, 523 (1968).

****** J. C. Cavagnol and W. R. Betker : in "The Practice of Gas Chromatog. raphy"; L.S. Ettre and A.Zlatkis (ed.), Interscience Pub., New York, 1967, p. 71.
ろなものを含みます。

炭素数 2 から炭素数 6 くらいまでのモノオール, ジオ 一ル，それにトリオールとしてのグリセロールは，水酸 基をとくに処理せずにガスクロマトグラフを行ならこと も可能ですが，またアセチル誘導体，トリメチルシリル (TMS) 誘導体としても分析されます．水酸基の露出し た状態では，どらしてもテイリングが著明で，クロマト グラムとしては $\mathrm{OH}$ を処理した誘導体より劣ります.

グリセロールの定量に関しては, ガスクロマトグラン を応用する方法は多数報告されています. TMS 誘導体 とする方法** (実施例 8 参照), アセチル誘導体とする 方法***, あるいは, イソプロピリデングリセロール****, トリベンゾェート***** などにして分析する方法が報告 されています.

長鎖アルコールのガスクロマトグラフによる分析方法 は, きわめて数多く報告されていますが******, 水酸基
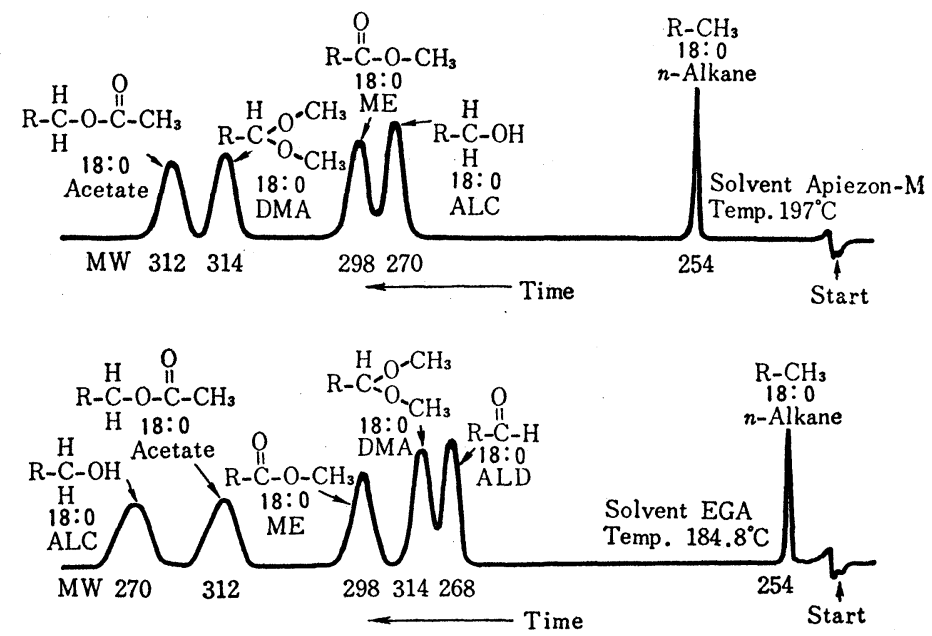

図 $2 \mathbf{C}_{18}$ アルカンの諸誘導体のガスクロマトグラフィー ALC : アルコール ME：メチルエステル DMA : ジメチルアセタール ALD : アルデヒド

[J. W. Farquhar: J. Lipid Res., 3, 21 (1962)] 
脂質または被験試料 数 $\mathrm{mg}$ を蓋付分解管にとり, 3 $\sim 5 \% \mathrm{HCl}$ メタノール $3 \mathrm{ml}$ を入れ, 沸騰水浴中に 3 時間保つ. 放冷後, 等量の石油エーテルで 3 回抽出し て，石油エーテル可溶分画を除去，残ったメタノール 分画に IR-4 B $(\mathrm{OH}$ 型, 脱水乾燥あるいはメタノール 㲘濁）を加兄て酸を除き，メタノール分画を蒸発乾固 する(注2).

ピリジン(注3) $1 \mathrm{ml}$ を加兄, 乾固残渣を充分に溶か し, $0.1 \mathrm{ml}$ の trimethylchlorosilane, $0.2 \mathrm{ml}$ の hexamethyldisilazane を加光(注4), $60^{\circ} \mathrm{C}$ 数分加温し, クロロホルム $5 \mathrm{ml}$, 水 $5 \mathrm{ml}$ を加えてはげしく振り, できるだけピリジンを水層に移す，水層を除き，再び 水を加光，この操作を 4 5 回繰り返す(注5). 最後に 容器のへりについた水分, クロロホルム層に浮く水滴 を，濾紙片で吸いとり，クロロホルム分画を濃縮す る(注6).

クロマトグラフの条件は, SE-30, $3 \%, 1.5 \mathrm{~m}, 100$ ${ }^{\circ} \mathrm{C}$ ，あるいはそれに準ずる条件なら，ほとんどの液相 ででる. 内部標準は 1,4-ブタンジオールを用いた(注7).
（注 1）この方法は, ペソトース,ヘキソース, ヘプトース をはじめとして，石油エーテルとメタノールで分配したとさ に,メタノール屓にくるハイドロオキシ化合物に適用される。 筆者らはこの方法を糖類の日常的な分析法として利用してい る. 脂質のガスクロマトグラフィー（Ｉ）の実施例 1 (Vol.

7, No. 12，p.745)を参照いただきたい.

（注 2）グリセロールのみを目的とするならば，とくに酸 を除く必要はない。

（注 3） ピリシンは充分に乾燥していることが重要. 蒸溜

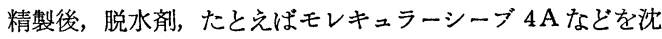
めておくとよい.

（注 4）あらかじめピリジンに加えておいてもよい.

Pierce Chemical 社より種々のシリル化郕が市販されている. たとえば TRI-SILZ.

（注 5）ピリシンを充分に除去しないと，溶媒部分のテイ リングがはげしくなり，トリトリメチルシリルグリセロール はテイリング部分にのってしま5。メタノール㬉からピリジ ンをとり去るには，少なくとも 4 5 回水で洗了必要がある.

（注 6）水が残ったまま濃縮すると, トリメチルシリルエ 一テルは簡単に加水分解してしまうから注意が必要。

（注 7） 内部標準は, 溶媒を濃縮したりする操作で揮発し てはならない.1,4-ブタンジオールが最適というわけではない. トリメチルシリルグリセロールに比して保持時間は長すぎる.

実施例 9]長鎖アルコールのトリフルオロアセテ

带鎖アルコール $1 \mathrm{mg}$ を蓋付試験管にとり, trifluoroacetic anhydride 無水トリフルオロ酢酸 $1 \mathrm{ml}$ を加 え, 15 分室温に放置した後, 過剩の無水トリフルオ 口酢酸和よび反応生成したトリフルオ口䣫酸(注2)を 窒素気流でとばし，改めて試料が期待する濃度になる ように無水トリフルオロ酢酸で溶かしな扎してガスク ロマトグラフの試料とする(注3).

（注 1）この方法は, 原則として他のハイドロオキシ, ポ リハイドロオキシ，アミン，アミノ化合物に適用することが できる. 試料が無水トリフルオロ酭酸となじまない場合, あ らかじめ種々の溶媒溶かしておくことが試みられている. たとえば, テトラヒドロフラン.

（注 2）大量のトリフルオロ酢酸があると，強い酸性のた めに, カラムの液相や検出器の金属部分に影響を及ぼす可能 性が否定できない.

（注 3）無水トリフルオロ酢酸で溶かしなおす代わりに, $1 \%$ 程度の無水トリフルオロ眽酸を含むへキサンを用いたり， なにも含まない有機溶媒を使用する人もある.（注 2) のよ らな臨念に対する配虑と思われる。

が遊離のままで存在することの保持時間に対する影響は, 液相の種類によって大きく異なり, ポリエステルのよう な極性液相では非常に長い保持時間が必要であり, SE30 のよらな無極性液相ではかなりはやく出ることが観 察されています. 図 2 は, 長鎖の末端基構造の保持時間 との関係が表わされています. とくに，遊離の水酸基の 挙動が注目されてよいでしょう.

図 3 にアルコールの分析例を示します.

コレステロールも長鎖アルコールと同じ性格を持ち,

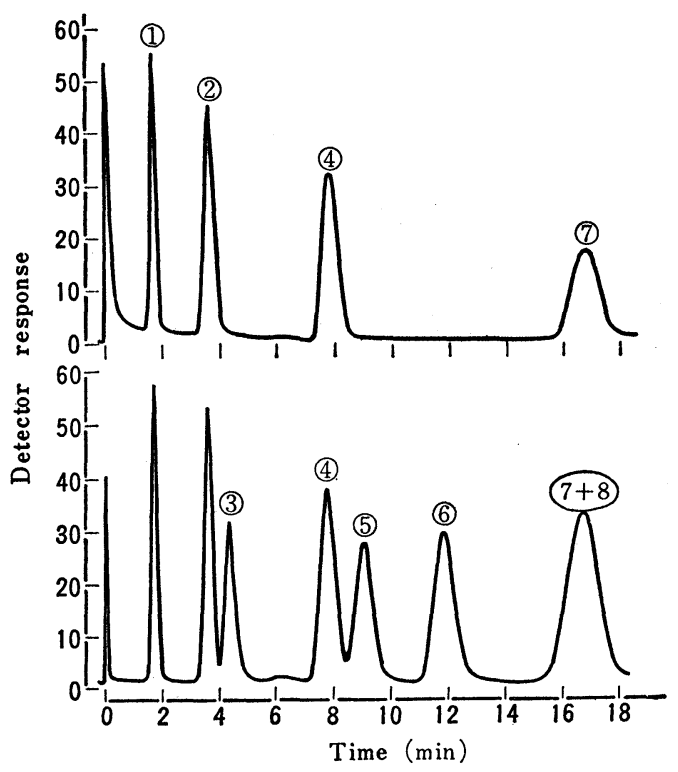

図 3 長鎖アルコールの TFA 誘導体のカススク ロマトクラフィー

(1) Myristyl, (2) Palmityl, (3) Palmitoleyl,

(4) Stearyl, (5) Oleyl, (6) Linoleyl,

(7) Arachidyl, (8) Linolenyl

カラム : EGSS-X, $130^{\circ} \mathrm{C}$

[R. Wood : J. Gaschromotog., 6, 94 (1968)]

長鎖アルコールと同様に無処理のままで, 無極性のカラ ムで分析することもできますし，また，3 位の水酸基を 
一州実施例 10] スフィンゴシン塩基の TMS 誘導体およびトリフルオロ酢酸誘導体の調製”

スフィンゴシンを含む脂質 数 $\mathrm{mg}$ を蓋付分解管に とり, 水性塩酸メタノール (conc. $\mathrm{HCl} 8.6 \mathrm{ml}$, 水 $9.4 \mathrm{ml}$ にメタノールを加えて $100 \mathrm{ml}$ にする) $3 \mathrm{ml}$ を加壳, $70^{\circ} \mathrm{C}, 18$ 時間加温する. 放冷後 $3 \mathrm{ml}$ の石 油エーテルで脂肪酸を抽出し, 別の容器に移す.この 操作を 3 回繰り返す. 残ったメタノール層に $5 \mathrm{ml}$ の 水を加え, ジェチルェーテル $3 \mathrm{ml}$ を加えて長鎖塩基 を抽出する.この操作を 3 回繰り返し, 集めたエーテ ルは同量の水で 1 回洗い, 乾燥後濃縮する. これにつ
いてのトリメチルシリル化(注1)またはトリフルオロア セチル化を行なう. その方法は実施例 8, 9 を参照の. こと.

（注 1） Carter, Gaver* はシリル化剤として, 乾燥ピリジ ソ $2 \mathrm{ml}$ に hexamethyldisilazane $2.6 \mathrm{ml}$ を加えよく攪汼, trimethylchlorosilane $1.6 \mathrm{ml}$ を追加，さらによくまぜる. この際生じた白沈は遠心して除き,上清をシリル化に用いる. スフィンゴシン $150 \mu \mathrm{g}$ に対して $50 \mu \mathrm{l}$ を要する.

* H. E. Carter and R. C. Gaver : J. Lipid Res., 8, 391 (1976).

\section{….. [実施例 11] スフィンゴシンより対応するアルデヒドの調製}

1〜5 mg のスフィンゴシンを potassium borate buffer $\mathrm{pH} 10,4 \mathrm{ml}$ と fluorodinitrobenzen $2 \mu 1$ を $1 \mathrm{ml}$ のエタノールに溶かしたものとの混液に加えて, $60^{\circ} \mathrm{C}$ に 30 分保つ. 冷却してからエーテルで抽出す る*(注1).

エーテル分画を濃縮乾固してから $1 \mathrm{ml}$ のベンゼン を加え $100 \mathrm{mg}$ の四酢酸鉛を加克, $50^{\circ} \mathrm{C}$ に 1 時間保 って酸化する. 反応終了後, 数 $\mathrm{ml}$ の水を加光てへキ
サンでできたアルデヒドを抽出する**(注2).

（注 1）DNPースフィンゴシンのみを得るためには, 薄畨 クロマトグラフで分取しなければならない。

（注 2）ガスクロマトグラフは，試料を作った日に行なっ た漂らがよい。

* K.-A. Karlsson : Nature, 188, 312 (1960).

** K.-A.Karlsson and E. Mårtensson: Biochem. Biophys. Acta, 152, 230 (1968).
TMS その他で処理することによってる分析可能です. 詳細はステロイドのガスクロマトグラフを参照してくだ さい.

\section{スフィンゴシン塩基のガスクロマトグラフィー}

スフィンゴミェリンや，いわゆるスフィンゴグリコリ ピドといわれる一群の脂質には, スフィンゴシン塩基と それに酸アミド結合した長鎖脂肪酸が基本構造になって, さらに各種の糖や，リン酸コリンなどが結合して, 生物 体に広く分布しています。

そのスフィンゴシン塩基の部分の構造は単一なもので はなく，ことにガスクロマトグラフ分析の導入によって， いろいろな類似体の存在が報告され，またそのうちのあ るものは, 精製分取途中の人工産物であったりしました. 1 つの方法は, 酸分解によってスフィンゴシン塩基を 得て, 過ヨウ素酸その他で酸化して長鎖アルデヒドにし てガスクロマトグラフを行なら方法です*.この方法は， 脂肪酸の混入があると結果を大きく誤らすことになるの で, カラムを用いて，スフィンゴシン塩基を脂肪酸から

* C. C. Sweeley and E. A. Moscatelli : J. Lipid Res., 1, 40 (1959).

** R. C. Gaver and C. C. Sweeley :J. Am. Oil Chemists' Soc., 42, 294 (1965).

**** 安藤進, 山川民夫 : 脂質生化学研究, 1969, p. 83.

**** A. J. Polito, T. Akita and C. C. Sweeley: Biochemistry, 7, 2609 (1968).

H. E. Carter and R. C. Gaver : J. Lipid Res., 8, 391 (1967).
精製分取しなければなりません.

もう 1 つの方法は, スフィンゴシン塩基をそのままト リメチルシリル誘導体**, トリフルオロ酢酸誘導体*** にして（実施例 10）, ガスクロマトグラフで分析する方 法です.この方法ですと，脂肪酸が多少混入していても， 保持時間から弁別することはむずかしくありません，た だ,トリメチルシリルとアミノ基との結合は搦く，GCMASS の結果もアミノ基は遊離の状態であることを示 していますが，もっとも，この部分のトリメチルシリル がぞの段階ではずれたのか，また最初から入らなかった のかは明らかでありません. その点, トリフルオ口酢酸 はアミノともかなり強い結合を作るので安定した結果が. 得られると思います.な抏，あらかじめ選択的に N-ア セチルに誘導してシリル化する方法もあります. 選択的 アセチル化は 100 200 $\mu \mathrm{g}$ の遊離塩基を新しく調製し たメタノール: 氷酢酸 $(4: 1)$ 混液 $50 \mu 1$ に溶かし, 室 温で 1 晚放置, 水 $50 \mu 1$ を加宇て約 1 時間扣いた後, 凍 結乾燥することによって得られます****.

アルデヒドについてはポリェスデル類, TMS, TFA 誘 導体については SE-30, OV-17，その他で分析可能です。

\section{グリセリドのガスクロマトグラフィー}

炭素数の合計が 60 を越えるものまでが，ガスクロマ トグラフによって分析されている例が報告されていまする。 トリグリセリドに関しては, 試料側の処理の問題はほ. 


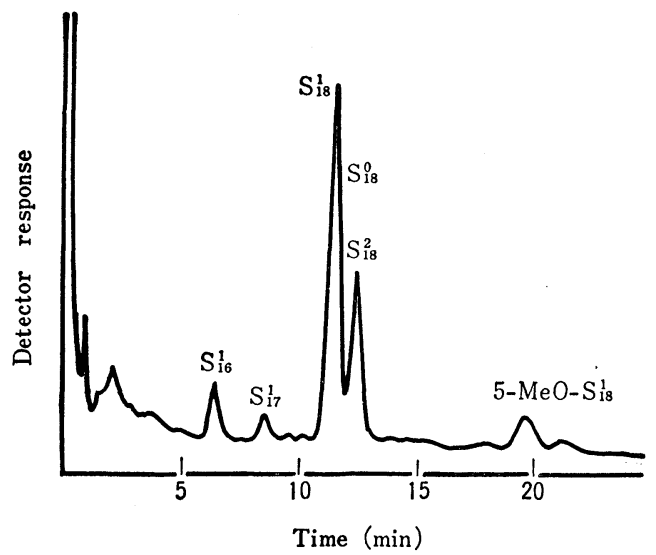

図 4 スフィンゴシン誘導体 (N-acetyl-Otrimethylsilyl) のガスクロマトグラム

試 料：ヒト plasma スフィンゴミリン カラム : $6 \mathrm{ft} \times 1 / 8$ inch U型ガラスカラム $3 \%$ XE-60 on Gas Chrom S (acid-wash, silanized)

In jection : $220 \sim 250^{\circ} \mathrm{C}$

[by A. J. Polito, T. Akita and C. Sweeley]

とんどないので，ガスクロマトグラフがうまくゆくか不 かは，まったく装置とカラムと運転技術の問題になって きます，原理的には，装置を非常に高い温度で限界いっ ぱいに感度を上げ，カラムは低液相で非常によくならさ れたものを用い，稀薄試料を微量注入するということに つきますが，一応それらについて整理してみます*。

カラムは文献的には 6 インチの短いものから 8 フィー トの長いものまであり，材質はステンレス，ガラスとも に報文がありますが，トリグリセ リドのカラム内損失については, ガラスのほうがよい性質を示しま す. しかし，試料室とガラスカラ ム, カラムと検出器をつなぐ部分 に耐熱ゴムを用いる方式では，こ の部分が高温に耐えられず，反復 使用ができにくいといら久点があ ります.いずれの材質のカラムを 使用するとしても，内面をシラン 処理をすることがすすめられてお

* A. Kuksis : in "Lipid Chromatographic Analysis," Vol. 1, G. V. Marinetti (ed.), Dekker, New York, 1967, p. 239. E. C. Horning, W. J. A. Vanden Heuvel and B. G. Creech : in "Methods of Biochemical Analysis," Vol.11, D: Glick (ed.), Wiley, New York, 1963, p. 69.
り，それる hexamethyldisilazane による処理よりは dimethyldichlorosilane による処理がよいという人も います。

液相は SE-30, QF-1, JXR (polysiloxane polymer)な ぞが用いられ，JX? が寿命が長く使用できます。濃度 は 1〜3\% で分析されています.

支持体は Gas Chrom Q，P や A な岕が用いられま すが，強くシラン処理されたものがよい性能它示します。

カラムの conditioning 注必要なものとされ， $3 \% \mathrm{JXR}$ で $350^{\circ} \mathrm{C}$ ，4 6 時間, SE-30 ではもっと長い時間が必 要だといわれます，この熱処理の過程に打いて，低分子 物質を追い出すのはもちろんですが，高分子どうしが互 いに cross linking したりして分析に最適な状態が得 られると考兄られます。

カラムの運転温度は， $350^{\circ} \mathrm{C}$ まで昇温できることが望 まれます．年温速度は通常 $1 \sim 4^{\circ} \mathrm{C} / \mathrm{min}$ ですが, $20^{\circ} \mathrm{C} /$ min などの例もあります. 検出器温度は $300 \sim 340^{\circ} \mathrm{C}$. 試料気化室温度は $320 \sim 350^{\circ} \mathrm{C}$ 程度で，極度に高すぎる ことはよくありません。

試料量は 1 ピーク当り $0.5 \sim 2 \mu \mathrm{g}$ で, $10 \mathrm{mg}$ 程度の 混合試料を $1 \mathrm{ml}$ のクロロホルムに溶かし，0.5〜1 $\mu 1$ 注入するといらことになります。

分離は，もちろん液相の性質にもよるのですが，大体 炭素数による分離で，二重結合の数を判別することは現 在期待できません．同様に，グリセロールの 1,2 位の 構造異性などを弁別することもできません．

定量性は, trioctanoin から trilinoleinくらいまでは,

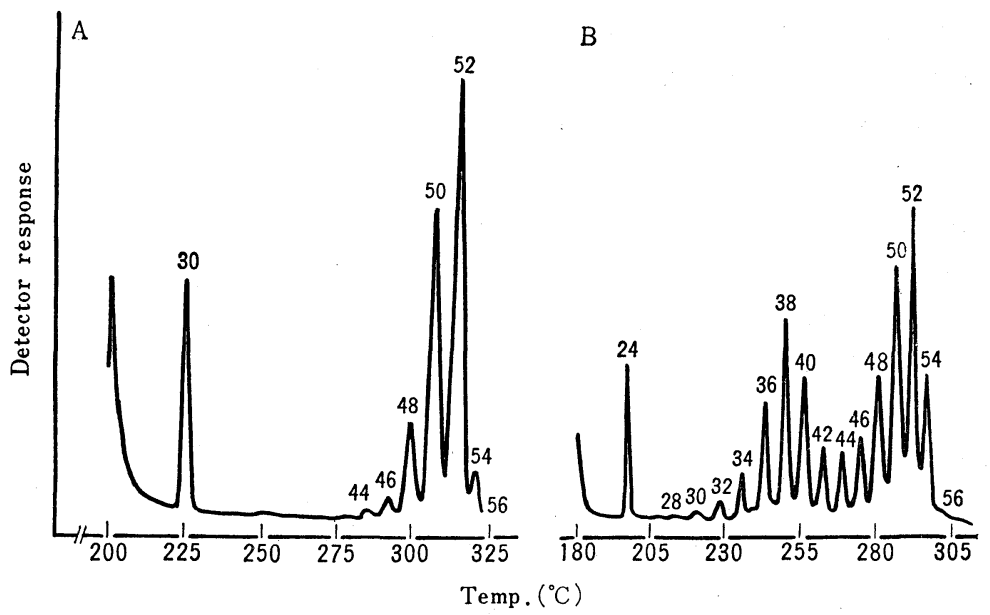

図 5 トリグリセリドのガスクロマトグラム

試 料：A ラード (tridecanoin 添加), B 牛乳脂肪（trioctanoin 添加） カラム : 20 inch $\times 1 / 8$ inch stainless steel, $30 \%$ JXR on Gas Chrom Q In jection : $280^{\circ} \mathrm{C}$, Detector $340^{\circ} \mathrm{C}$ [by A. Kuksis] 


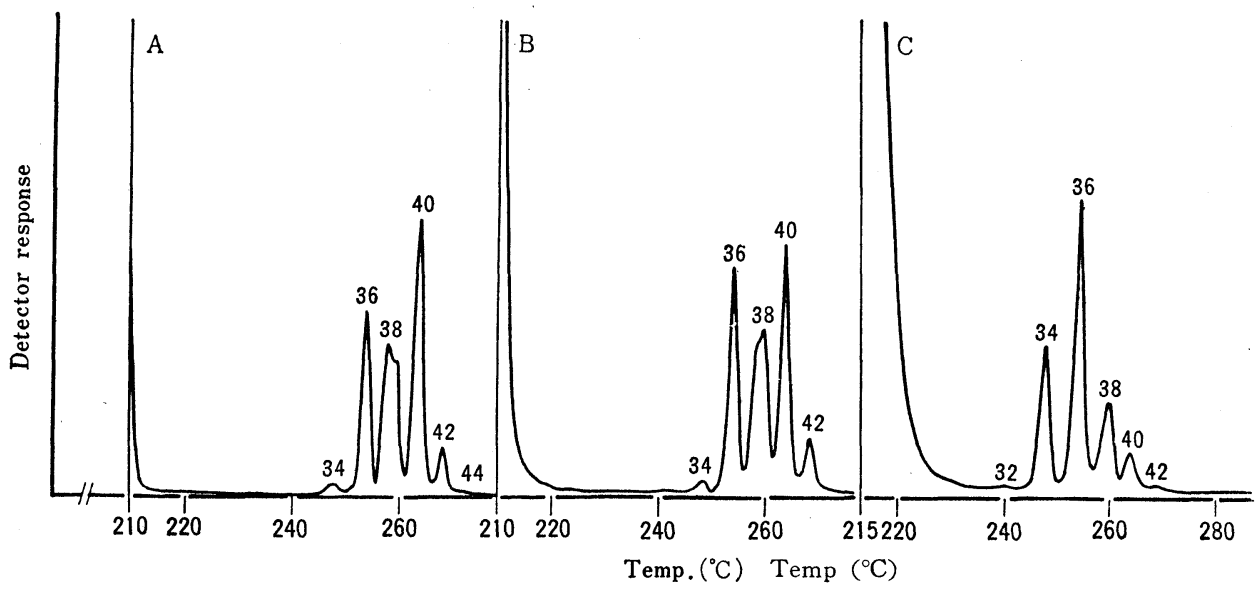

図 6 ジグリセリドのアセチル誘導体のガスクロマトグラム

試 料：A ヒト肝レシチソのジグリセリド， B ヒト plasma レシチンのジグリセリド, C ヒト赤血球レシチンのジグリセリド

カラム : 18 inch $\times 1 / 8$ inch stainless steel, $3 \%$ JXR on 100 120 mesh Gas Chrom Q Injection : $300^{\circ} \mathrm{C}$, Detector : $350^{\circ} \mathrm{C}$

[by A. Kuksis, W. C. Breckenridge, L. Marai and O. Stachnyk]

\section{[実施例 12] 溥グリセ体の製取}

1〜3 mg のジグリセリドをとり, 無水酢酸とピリジ ン混液 $(10: 1, \mathrm{v} / \mathrm{v}) 0.1 \mathrm{ml}$ を加え室温に放置する. クロロホルムに溶かし, 水で繰り返し洗えば過剩の反 応試薬を除き去ることができる.

面債比が重量比に等しいと考えてよいようですが，tribehenin $(C=66)$, trierucin $(C=66)$ になると, 面積は 実際の重量より小さくなると報告されています*.

トリグリセリドの分析で最も悩まされるのは, 装置の 高温度に拈ける安定性もさることながら，ゴーストピー クの出現です.すなわち, 分析を繰り返していますと, 試料を入れないで昇温操作をしただけで, トリグリセリ ドの出現すべき位置に，まさにそれらしいピークが実に きれいに出てくる場合があります。括そらく, 試料室周 辺に，1回で気化されなかった試料が付着して，次回の 昇温操作で自動的に出てくるもののようですが，よく注 意しないと実験結果の判断を誤ることになります．いっ たんこのゴーストピークが出はじめると, 除去するのが なかなかもずかしく，カラムの詰め替光洗浄や，試料室 网辺の大掃除が必要になります.

ジグリセリドは天然にも存在しますし，またのちに述 ベるグリセロリン脂質の分析の際にも, 結局ジグリセリ ドとして分析されますので，その分析技法の重要性は，

* C. Litchfield, R. D. Harlow and R. Reiser : J. Am. Oil Chemists' Soc., 42, 849 (1965).

A. Kuksis and W. C. Breckenridge : J. Am. Oil Chemists' Soc., 42, 978 (1965).

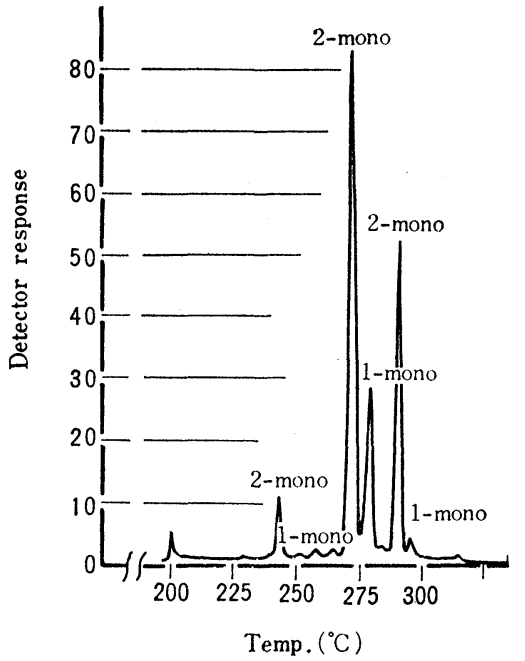

図 7 モノグリセリドのジブチル誘導体のガス

クロマトクラム

試、料：モノミリスチン，モノパルミチン，モノステアリン カラム : $5 \mathrm{ft} \times 1 / 8$ inch stainless steel

$5 \%$ SE-30 on silanized Chromosorb W

Injection : $280^{\circ} \mathrm{C}$, Detector : $340^{\circ} \mathrm{C}$ [by A. Kuksis]

最近急速に高まったといえましょう。

試料処理は, 高級アルコールと同じで, 薄い SE-30 カラムですと未処理のままでカラムから流出させること も不可能ではありませんが，アセチル化したり（実施例 12)，トリメチルシリル化したりして分析するほうが一 般的です.

カラムその他運転条件は,トリグリセリドの場合と同 じと考えてよいでしょう，構成脂肪酸の炭素数の少ない 
1〜 $5 \mathrm{mg}$ の試料を $5 \mathrm{ml}$ の充分に脱水したアセトン に溶かし，5１0 10 の過塩素酸（72\%）を加光，箃 重に蓋をして室温で 30 分振盪する。 この反応混合物 を, Silica Gel の薄層で, ヘキサン : エーテル (90:
10）を用いて展開， $R f 0.6$ 付近のオパール光の見ら れる部分をはぎとり, エーテルで抽出, ガスクロマト グラフの試料とする.

\section{TMS 誘導体の製取}

$60^{\circ} \mathrm{C}$ で 30〜60 分間保つ(注1). 反応液はそのままガ スクロマトグラフで分析する.

（注 1）この反応で得られるジグリセリドは，1，2-おょ び 1,3-ジグリセリドの双方である.
ほうでは, 1,2-ジグリセリドと 1,3-ジグリセリドの分 別が可能ですが，ジステアリン程度ですと肩を作るくら いで, 完全分離には至っていません. それに, エステル 結合の migration という複雑な問題がつきまといます.

モノグリセリドは，前二者に比べるとはるかに分析は 容易になり，その処理は高級アルコールに準じて考えれ ばよいでしょう，ただ，注意しなければならないのは， ガスクロマトグラフによって 1-mono と 2-mono とを 分離することはむずかしくありませんが，ジグリセリド の場合と同様に試料を作製する段階で, そしてガスクロ マトグラフの装置の中で, エステルの migration が起 こって, 1-mono の単一のピークしか得られない場合が あることです. 結果の判断に注意を要します.

ところで, エステル結合の代わりにェーテル結合を持 つプラスマローゲン型のものをここで考虑に入れねばな らないでしょう。

トリグリセリドとそれに対応する O-alkyl diglyceride とをガスクロマトグラフで弁別す ることは至難です. また，ジグリセリドと，そ れに対応する O-alkyl monoglyceride とを升 別することも，今日では報告はありません，そ して, 1-monoglyceride と 1-0-alkyl glycerol とを区別することも容易ではありません．今の ところ, Silica Gel の薄層を用いて O-alkyl を持つるのと持たぬものとを別けて，それぞれ を分析する方法がとられています。

\section{リン脂翼のガスクロマトグラフィー}

\section{グリセロリン脂質を無傷のままでガスクロマ}

* M. G. Horning, G. Casparrini and E.C. Horning : in "Advances in Chromatography", A. Zlatkis (ed.), Preston Technical Abstracts Company, 1969, p. 137.
トグラフで分析することは，今日成功していません，た とえば, レシチンをトリメチルシリル化してガスクロマ トグラフによって分析するといら試みで, 得られた結果 は, ジグリセリドのトリメチルシリル誘導体のクロマト グラムでした．シリル化剤とともにグリセロリン脂質を 高温にするとリン酸エステルの結合が切れてしまうこと が、ほぼ確認されています*。

しかし，レシチンがその構成脂肪酸の種類によって， 数多くの分子種から成るものであることは周知のことで あり，それを調べるためにはジグリセリドを調べればよ いことも当然といえます. 現在, フェニルェーテルと加 温することによってリン酸エステルを切ったり，ホスホ リパーゼ C*を使ってジグリセリドを得て, そのシリル 誘導体や，アセチル誘導体を分析する方法が行なわれて います，その結果は，現状ではそれほど実りの多いとい

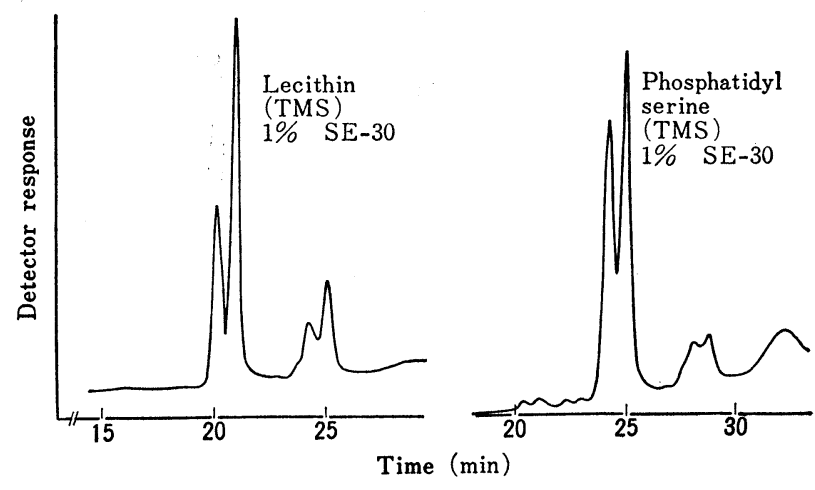

図 8 リン脂質の TMS 誘導体のガスクロマトグラム

試 料: 卵黄レシチンおよび市販ホスファチジルセリン

処 理: Phenyl ether 中で 5 分間 $250^{\circ} \mathrm{C}$ に加熱後 BSTFA 処理 を行なった.

カラム : $12 \mathrm{ft} \times 4 \mathrm{~mm}$ W型ガラスカラム

Injection : $260^{\circ} \mathrm{C}$, Detector : $300^{\circ} \mathrm{C}$

Programming : $270^{\circ} \mathrm{C}$ より $2^{\circ} \mathrm{C} / \mathrm{min}$ [by M.G.Horning, G. Casparrini and E.C.Horning] 
....... 実施例 15] スフィンゴミェリンの TMS 誘導体の調製

スフィンゴミエリン 1〜2 $\mathrm{mg}$ をとり, $0.1 \mathrm{ml}$ の る.

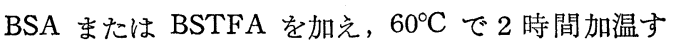

……実施例 16] セラミドの TMS 誘導体およびヘブタフルオロブチル誘導体の調製.

$1 \sim 2 \mathrm{mg}$ のセラミドをとり, $0.1 \mathrm{ml}$ の trimethylsilylimidazole (TSIM) を加光, $60^{\circ} \mathrm{C}$ で 3 時間加温 する.さらに $0.1 \mathrm{ml}$ の BSA と $0.05 \mathrm{ml}$ の TMCS を加え， $60^{\circ} \mathrm{C}$ で 1 時間加温する. この $2 \sim 4 \mu 1$ を分 析に供する。
1〜2 mg のセラミドを $0.2 \mathrm{ml}$ の N-heptafluorobutyrylimidazole に溶かし， $60^{\circ} \mathrm{C} て ゙ 2$ 時間加温する. 生成物はへキサンで抽出する(注 1).

（注 1）この誘導体の分析は $5 \%$ の SE-30 カラムで行な 5.

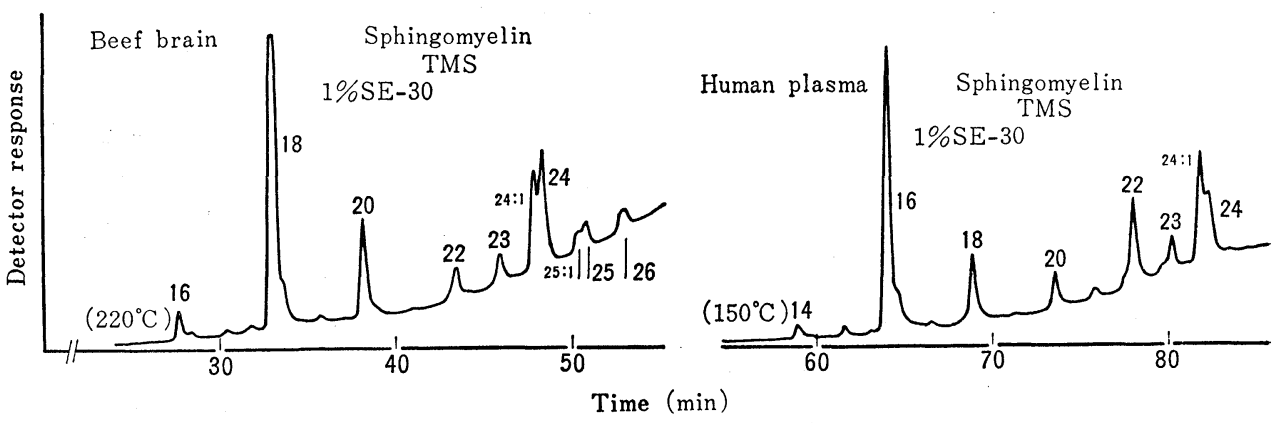

図 9 スフィンゴミエリンの TMS 誘導体のクロマトグラム

試 料: 牛脳およびヒト plasma スフィンヨ゙ミエリン

カラム : $12 \mathrm{ft} \times 4 \mathrm{~mm}$ W型ガラスカラム, $1 \% \mathrm{SE}-30$ on 100 120 mesh Gas Chrom P (acid-wash, silanized)

In jection : $260^{\circ} \mathrm{C}$, Detector : $300^{\circ} \mathrm{C}$

Programming : $220^{\circ} \mathrm{C}$ より $2^{\circ} \mathrm{C} / \mathrm{min}, 150^{\circ} \mathrm{C}$ より $2^{\circ} \mathrm{C} / \mathrm{min}$

[by M.G.Horning, G. Casparrini and E. C. Horning]

らものではありませんななぜらば，ジグリセリドの分＼cjkstart度で，二重結合の数による差の分別に成功していないこ 析の項で触れたように，現在は炭素数による差を出す程 と，そしてエステルの migration の問題が複雑にから

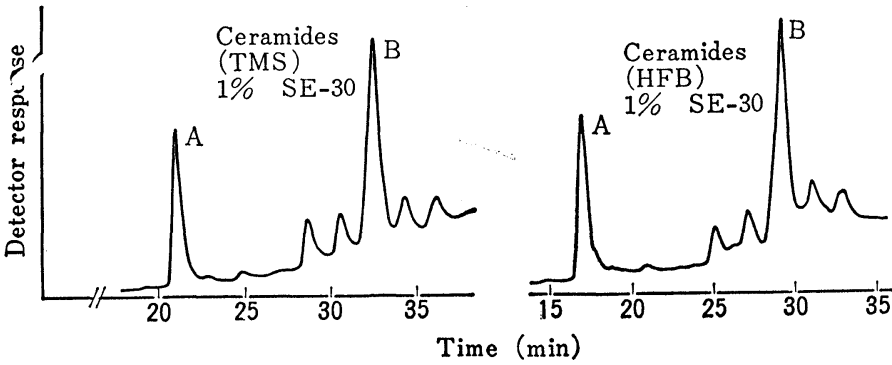

図 10 セラミドの TMS 誘導体と HFB 誘導体のクロマトグラム

試 料:市販セラミド, A $\alpha$-hydroxystearoyl, B $\alpha$-hydroxylignoceroyl カラム : $12 \mathrm{ft} \times 4 \mathrm{~mm} \mathrm{~W}$ 型ガラスカラム

$1 \%$ SE-30 on $100 \sim 120$ mesh Gas Chrom P

Injection : $260^{\circ} \mathrm{C}$, Detector : $300^{\circ} \mathrm{C}$

Programming : $270^{\circ} \mathrm{C}$ より $2^{\circ} \mathrm{C} / \mathrm{min}$

[by M.G.Horning, G. Casparrini and E.C.Horning]
み合ってくることなどがその理由です.

スフィンゴミエリンのガスクロマトグ

ラフも同様に試みられています. 処理力 法も同様で, フェニルェーテル中で強熱 するとホスホリルコリンを除くことがで きますが，この処理をせずにトリメチル シリル化したものをガスクロマトグラフ で分析した結果は，脱水したもののピー クが出ていることが Mass Spectrum で 確認されています。

\section{糖脂質のガスクロマトグラフィー** \\ セレブロシドのガスクロマトグラフ分}

析を行なったと Horning の報告にめり
* A. Kuksis, W. C. Breckenridge, L. Marai and O. Stachnyk: J. Am. Oil Chemists' Soc., 45, 537(1968).

** M.G.Horning, G. Casparrini and E.C.Horning : in "Advances in Chromatography", A. Zlatkis (ed.), Preston Technical Abstracts Company, 1969, p. 137. ますが，詳細はわかりません，七ラミドに関しては，ト リメチルシリル誘導体とヘプタフルオロブチル (HFB) 誘導体で分析した例が報告されています。（拉わり） 